\title{
BMP4 inhibits the proliferation of breast cancer cells and induces an MMP-dependent migratory phenotype in MDA-MB-231 cells in 3D environment
}

Minna Ampuja ${ }^{1,2}$, Riikka Jokimäki ${ }^{1,2}$, Kati Juuti-Uusitalo ${ }^{1}$, Alejandra Rodriguez-Martinez ${ }^{1,2}$, Emma-Leena Alarmo ${ }^{1,2}$ and Anne Kallioniemi ${ }^{1,2^{*}}$

\begin{abstract}
Background: Bone morphogenetic protein 4 (BMP4) belongs to the transforming growth factor $\beta$ (TGF- $\beta$ ) family of proteins. BMPs regulate cell proliferation, differentiation and motility, and have also been reported to be involved in cancer pathogenesis. We have previously shown that BMP4 reduces breast cancer cell proliferation through G1 cell cycle arrest and simultaneously induces migration in a subset of these cell lines. Here we examined the effects of BMP4 in a more physiological environment, in a 3D culture system.

Methods: We used two different 3D culture systems; Matrigel, a basement membrane extract from mouse sarcoma cells, and a synthetic polyethylene glycol (PEG) gel. AlamarBlue reagent was used for cell proliferation measurements and immunofluorescence was used to determine cell polarity. Expression of cell cycle regulators was examined by Western blot and matrix metalloproteinase (MMP) expression by qRT-PCR.

Results: The MCF-10A normal breast epithelial cells formed round acini with correct apicobasal localization of a6 integrin in Matrigel whereas irregular structures were seen in PEG gel. The two 3D matrices also supported dissimilar morphology for the breast cancer cells. In PEG gel, BMP4 inhibited the growth of MCF-10A and the three breast cancer cell lines examined, thus closely resembling the 2D culture conditions, but in Matrigel, no growth inhibition was observed in MDA-MB-231 and MDA-MB-361 cells. Furthermore, BMP4 induced the expression of the cell cycle inhibitor p21 both in 2D and 3D culture, thereby partly explaining the growth arrest. Interestingly, MDA-MB-231 cells formed large branching, stellate structures in response to BMP4 treatment in Matrigel, suggestive of increased cell migration or invasion. This effect was reversed by Batimastat, a broad-spectrum MMP inhibitor, and subsequent analyses showed BMP4 to induce the expression of MMP3 and MMP14, that are thus likely to be responsible for the stellate phenotype.
\end{abstract}

Conclusions: Taken together, our results show that Matrigel provides a more physiological environment for breast epithelial cells than PEG gel. Moreover, BMP4 partly recapitulates in 3D culture the growth suppressive abilities previously seen in 2D culture and induces an MMP-dependent migratory phenotype in MDA-MB-231 cells.

Keywords: 3D culture, Matrigel, Breast cancer, BMP4, Proliferation, Migration

\footnotetext{
* Correspondence: anne.kallioniemi@uta.fi

'Institute of Biomedical Technology, University of Tampere and BioMediTech, Tampere, Finland

${ }^{2}$ Fimlab Laboratories, Tampere, Finland
} 


\section{Background}

Bone morphogenetic protein 4 (BMP4) is a growth factor that belongs to the bone morphogenetic protein (BMP) family, which comprises the majority of the transforming growth factor $\beta$ (TGF- $\beta$ ) -superfamily [1]. BMPs are extracellular ligands that bind serine/threonine receptors on the cell membrane and signal through intracellular SMAD mediators as well as through other pathways such as the MAP kinase pathway. BMPs were first found due to their bone-inducing effects and later studies showed them to be also powerful developmental regulators. For example, BMP4 is involved in gastrulation, mesoderm formation, hematopoiesis and the development of several organs and tissues including mammary gland [2-4].

Due to their multifunctionality, BMPs have been increasingly studied as potential players in cancer. BMP4 expression in cancer varies and both increased and decreased expression has been reported depending on the tissue of origin [5]. In breast cancer, strong BMP4 expression has been found in both cell lines and tissues [6-8] and immunohistochemical data indicate that BMP4 protein is expressed in one fourth to half of primary tumors [9]. Functional studies in multiple malignancies suggest that BMP4 typically causes reduced growth and increased migration of cancer cells [5]. We have previously shown, using a large set of breast cancer cell lines, that BMP4 treatment systematically inhibits proliferation in all cell lines and simultaneously increases migration of MDA-MB-231, MDA-MB-361 and HCC1954 cells, but reduces migrativeness of T-47D cells [10]. Similarly, Guo and colleagues [6] demonstrated increased migration and decreased proliferation upon BMP4 overexpression in MDA-MB-231 and MCF-7 breast cancer cells. These data were corroborated by an in vivo study where inhibition of BMP4 signaling decreased metastasis of MDAMB-231 breast cancer cells [11]. Yet there is one study where BMP4 reduced migration of MDA-MB-231 cells [12]. Nevertheless, the majority of the data implies that BMP4 has a dualist effect on breast cancer cells, with inhibition of cell proliferation and induction of a migratory phenotype.

The aforementioned in vitro functional studies were done using cells growing as two-dimensional (2D) monolayer. However, there is an increasing interest in culturing cells in a more biologically relevant three-dimensional (3D) environment [13]. This has been generally achieved by growing cells in synthetic scaffolds or gels of biological or synthetic origin [14]. Matrigel, basement membrane extract from mouse sarcoma, is the most commonly used biological scaffold and consists mainly of laminin, collagen IV and various growth factors [15]. Other biological materials that are often used include collagen, alginate and hyaluronic acid [14]. Synthetic gels have been developed as alternatives to the biological gels due to the difficulties in defining the exact composition of the biological materials and the fact that they may suffer from batch-to-batch variability [14]. Synthetic gels, mainly different polymers, such as polyethylene glycol and polyvinyl alcohol, have a constant composition and are easy to manipulate. However, they may not adequately represent the complicated extracellular matrix (ECM) that surrounds cells in tissues $[14,16]$.

Various cell types, including epithelial, neural and endothelial cells, have been successfully grown in 3D and are capable of forming structures that resemble the normal tissue organization [15]. For example, normal immortalized mammary epithelial cells, such as the MCF-10A cells, form polarized acini structures in Matrigel, reminiscent of the normal breast architecture [17], whereas breast cancer cells generate more variable structures [18]. Similarly, biologically appropriate cellular organization has been observed e.g. for epithelial and neural cells in different synthetic gels [19-21]. More importantly, the shift from $2 \mathrm{D}$ to $3 \mathrm{D}$ culture also results in changes in gene expression in multiple tissue types [13,22-25]. For example, breast epithelial cells begin to produce milk proteins when grown in Matrigel [25].

Previous data from us and others showed that BMP4 is able to reduce the growth of breast cancer cells whilst inducing cell migration and invasion $[6,10,11]$. Here we utilized two different $3 \mathrm{D}$ culture systems to evaluate whether these phenotypes persist under more physiological culture conditions and further explored the mechanisms of BMP4-induced changes in cell proliferation and mobility.

\section{Methods}

\section{Cell lines}

The MCF-10A, MDA-MB-231, MDA-MB-361, BT-474 and T-47D cell lines were purchased from ATCC (Manassas, VA, USA) and cultured according to ATCC instructions, except for MCF-10A, which was maintained as previously described [17]. In 3D experiments, MDAMB-231 and MDA-MB-361 cells were cultured in DMEM (Sigma-Aldrich, St. Louis, MO, USA). For MCF-10A cells a reduced concentration of $\operatorname{EGF}(5 \mathrm{ng} / \mathrm{ml})$ was used in Matrigel [17].

\section{BMP4 and inhibitor treatments}

rhBMP4 (100 ng/ml, R\&D Systems, Minneapolis, MN, USA), BMP antagonist Gremlin $(1 \mu \mathrm{g} / \mathrm{ml}, \mathrm{R} \& D$ Systems), MMP inhibitor Batimastat (10 $\mathrm{MM}$, Millipore, Billerica, MA, USA) or a combination of these was added to the medium at the start of the experiments and replenished every two to three days as the medium was exchanged. Vehicle-treated cells received BMP4 dilution buffer (4 mM HCl with 0.1\% BSA), Gremlin dilution buffer $(0.1 \%$ BSA in PBS), Batimastat dilution buffer (DMSO), 
or a combination of these. All experiments were done in two to six replicates and were repeated at least twice.

\section{Cell proliferation assay}

Medium with $10 \%$ alamarBlue (Invitrogen) was added to the cells and incubated for 1 hour (2D culture) or 4 hours (Matrigel and PEG gel). Medium was collected and fluorescence (excitation wavelength $560 \mathrm{~nm}$, emission wavelength $590 \mathrm{~nm}$ ) measured using Tecan infinite F200 Pro plate reader (Tecan, Männedorf, Switzerland). Additionally, the number of cells in 2D culture was counted using the Z1 Coulter Counter (Beckman Coulter, Fullerton, CA) at indicated time points. The experiments were done in four to six replicates and repeated at least twice.

\section{Cell cycle}

MCF-10A cells were cultured on 24-well plates and analyzed 3 and 5 days after first addition of BMP4. The cells were stained with PI as described [26]. The cell cycle distribution was determined using the Accuri C6 flow cytometer (Accuri, Ann Arbor, MI, USA) and ModFit LT 3.0 (Verity software house, USA). The experiment was performed twice with six replicates.

\section{D Matrigel assay}

Cells were cultured on growth factor-reduced Matrigel (BD Biosciences, Franklin Lakes, NJ, USA) using the overlay method [17]. Briefly, 4-chambered Lab-Tek chamber slides (Nalge Nunc International, Rochester, NY, USA) or 24-well plates were coated with Matrigel. Cells $\left(2.0 \times 10^{4}\right.$ cells $/ \mathrm{ml}$ for MDA-MB-231 and T-47D, $2.4 \times 10^{4}$ cells $/ \mathrm{ml}$ for MCF-10A, $6.0 \times 10^{4}$ cells $/ \mathrm{ml}$ for BT-474 and $1.2 \times 10^{5}$ cells/ml for MDA-MB-361) suspended in 2.5\% Matrigel solution were added on coated chamber slides and allowed to grow up to 17 days.

\section{D PEG gel assay}

MMP-degradable polyethylene glycol (PEG) gel with RGD peptides was purchased from QGel (Lausanne, Switzerland). Briefly, $400 \mu \mathrm{l}$ of Buffer A was mixed with QGelTM MT 3D Matrix powder, before addition of $100 \mu \mathrm{l}$ of cell suspension (given a final concentration of $1.4 \times 10^{5}$ cells $/ \mathrm{ml}$ for MCF- $10 \mathrm{~A}, 1.0 \times 10^{5} \mathrm{cells} / \mathrm{ml}$ for MDA-MB-231, $8.0 \times 10^{4}$ cells $/ \mathrm{ml}$ for T-47D, and $4.0 \times 10^{5}$ cells/ml for MDA-MB-361). Drops of $40 \mu \mathrm{l}$ were applied into a disc caster and after $30 \mathrm{~min}$ incubation at $37^{\circ} \mathrm{C}$ the gelled discs were removed and placed on 24-well plates with $1 \mathrm{ml}$ of medium per well. The cells were allowed to grow up to 18 days.

\section{Immunofluorescence}

The MCF-10A cells in Matrigel and PEG gel were fixed in $4 \%$ paraformaldehyde for 1 hour at $37^{\circ} \mathrm{C}$ followed by permeabilization with $0.1 \%$ Triton-X100 for $45 \mathrm{~min}$ at room temperature and blocking with 3\% BSA for 1.5 hours at $37^{\circ} \mathrm{C}$. The fixed cells were incubated with mouse monoclonal anti- $\alpha 6$ integrin antibody (1:300, Abcam, Cambridge, UK) for 1.5 hours at $37^{\circ} \mathrm{C}$. The secondary goat anti-mouse Alexa Fluor 488 (1:200, Invitrogen) was used similarly. The cells were stained with DAPI (Invitrogen) and mounted with Vectashield (Vector Laboratories, Burlingame, CA, USA). Images were taken with Zeiss Axio Imager. M2 microscope (Carl Zeiss, Oberkochen, Germany) connected to an ApoTome slider module (Carl Zeiss).

\section{Image analysis}

Images were taken from the cells in Matrigel and PEG gel using Olympus IX71 microscope (Olympus, Tokyo, Japan) and processed with ImageJ (U.S. National Institutes of Health, Bethesda, MD, USA). Four images from each experiment at designated time points were analyzed and the average area covered by the cells was calculated.

\section{Protein extraction}

The cells were collected 24 hours or 5 days (2D culture) and 4 or 7 days (Matrigel) after first addition of BMP4. Matrigel was first dissolved by adding cold PBS with $5 \mathrm{mM}$ EDTA and the cells were kept on ice for $15 \mathrm{~min}$. The cell-Matrigel solution was then collected, kept on ice for $30 \mathrm{~min}$ and centrifuged for $15 \mathrm{~min}$ at $3300 \times \mathrm{g}$, at $4^{\circ} \mathrm{C}$. Cells were lysed and protein concentration measured as previously described [10].

\section{Western blot}

Fifty $\mu$ g of protein was loaded onto SDS-PAGE gels. After gel electrophoresis, the proteins were transferred to a PVDF membrane. The following primary antibodies (Santa Cruz Biotechnology, CA, USA) and dilutions were used: p21 (1:100), Cdk4 (1:1000), Cdc2 (1:1000), p-Cdc2 (Thr14/Tyr15, 1:200), p27 (1:500), p16 (1:100), p15 (1:200), Cyclin B1 (1:200), Cyclin B2 (1:100) and Cyclin D1 (1:200). All antibodies were rabbit polyclonal, with the exception of p16 (mouse monoclonal) and Cyclin B2 (goat polyclonal). In addition, a mouse monoclonal anti-GTF2H1 antibody (1:1000, Abcam) was used. Proteins were detected using the BM Chemiluminescence Western Blotting kit (Roche, Mannheim, Germany) according to manufacturer's instructions. Anti-mouse/ rabbit secondary antibody (1:5000, Roche) was used for all antibodies, except for Cyclin B2, which was detected with anti-goat secondary antibody (1:5000, Santa-Cruz Biotechnology). The membranes were stripped and probed with $\beta$-tubulin (Sigma-Aldrich) as a loading control. 


\section{Quantitative RT-PCR}

The expression of $M M P-1,-2,-3,-7,-9,-14$ and ADAM17 was examined in BMP4- and vehicle-treated MDA-MB-231 and BT-474 (MMP3 and MMP14 only) cells grown for 14 days in Matrigel. The cells were harvested as described above for protein extraction. Total RNA was extracted using RNeasy Mini kit (Qiagen, Valencia, CA) and was reverse transcribed using SuperScriptTM III First-Strand Synthesis System for RT-PCR (Invitrogen) as described [7]. qRT-PCR was performed using gene specific primers and UPL probes (Roche, Additional file 1: Table S1) and the LightCycler equipment (Roche) as described [27] with $1.2 \mu \mathrm{M}$ concentration of primers and probes and the following program: 10 min denaturation at $95^{\circ} \mathrm{C}$ followed by 45 cycles of $10 \mathrm{~s}$ denaturation at $95^{\circ} \mathrm{C}, 10 \mathrm{~s}$ annealing at $55^{\circ} \mathrm{C}$ and $15 \mathrm{~s}$ elongation at $72^{\circ} \mathrm{C}$. The experiments were done in three replicates and the expression levels were normalized using Phosphoglycerate kinase 1 (PGK1) housekeeping gene.

\section{Statistical analyses}

The difference between BMP4- and vehicle-treated samples in cell proliferation and area analysis was evaluated using the Mann-Whitney test with GraphPad Prism 4. (GraphPad Software, La Jolla, CA, USA). A P-value of less than 0.05 was considered significant.

\section{Results}

BMP4 inhibits the growth of MCF-10A cells in both 2D and $3 D$ cell culture

We began the study using an immortalized breast epithelial cell line MCF-10A, which is widely used in 3D cultures. However, since no previous data existed, we first tested the effects of BMP4 on these cells in standard 2D culture. Similar to breast cancer cell lines [10], BMP4 decreased the proliferation of the MCF-10A cells as determined by cell counting and alamarBlue (Figure 1A). A highly significant decrease in cell number was evident at day 3 and day 6 (42\% and 50\%, respectively, as compared to vehicle; $\mathrm{P}<0.01)$.

In 3D assays, both biological (Matrigel) and synthetic (polyethylene glycol, PEG gel) materials were used. In Matrigel, MCF-10A cells formed round acini-like structures with correct apicobasal polarity of the acini, as illustrated by the basal localization of $\alpha 6$-integrin (Figure 1B, left panel). In contrast, MCF-10A cells grown in PEG gel demonstrated a disordered structure with no obvious lumen formation and no basal localization of $\alpha 6$-integrin (Figure 1B, right panel).

When MCF-10A cells in Matrigel were treated with BMP4 (100 ng/ml), there was no change in the acinar morphology but proliferation of the cells was reduced (Figure $2 \mathrm{~A}-\mathrm{C}$ ). The proliferation rate (as measured by

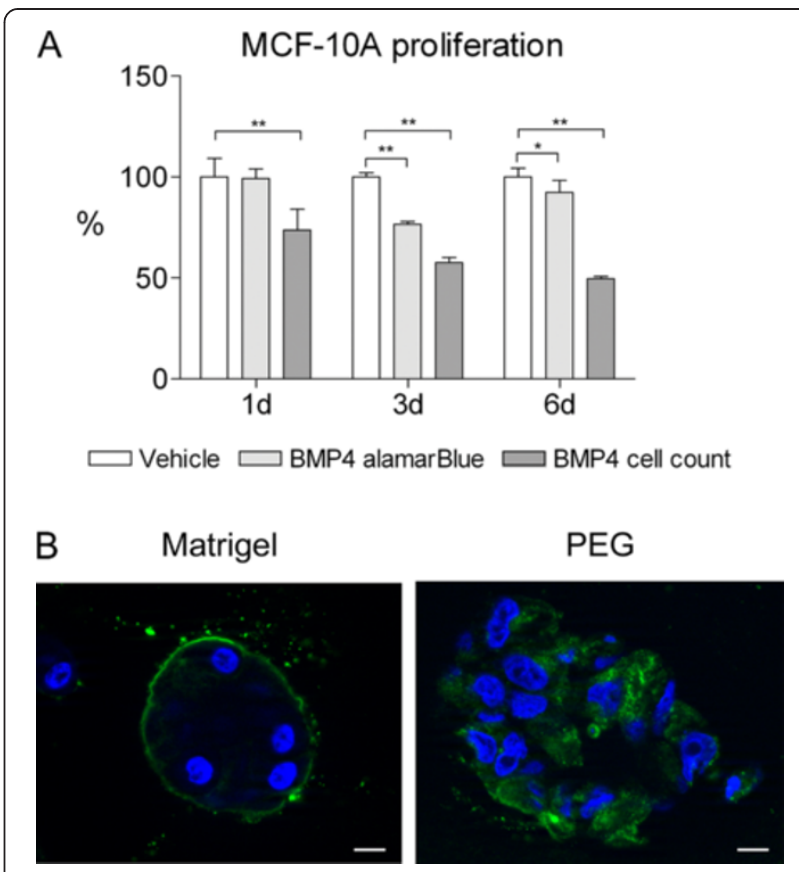

Figure 1 Characterization of MCF-10A cells in 2D and 3D culture. (A) BMP4 treatment significantly reduces the proliferation of MFC-10A cells in 2D culture. Cells were grown in the presence of $100 \mathrm{ng} / \mathrm{ml}$ BMP4 or vehicle and proliferation was measured using the alamarBlue reagent and by counting the cells at indicated time points. Relative proliferation (mean + s.d.) compared to vehicle is shown. ${ }^{*} P<0.05$, ${ }^{* *} P<0.01$. (B) MCF-10A cells form polarized structures in Matrigel but not in PEG gel. The cells were grown in Matrigel for 14 and in PEG gel for 11 days, fixed, and immunofluorescently labeled with polarization marker a6-integrin antibody (green). The nuclei were stained with DAPI (blue). Images were taken with Zeiss Axio Imager.M2 microscope. Scale bar $10 \mu \mathrm{m}$.

alamarBlue) was decreased by $41 \%$ at day 14 in BMP4treated cells as compared to vehicle-treated cells $(\mathrm{P}<0.05$, Figure 2B). Accordingly, BMP4 also significantly decreased the size of the acini structures as evidenced by a $40 \%$ reduction in the total area covered by the cell clusters at day $14(\mathrm{P}<0.05$, Figure $2 \mathrm{C})$.

In PEG gel, vehicle-treated MCF-10A cells mainly formed round cell clusters with occasional protrusions whereas BMP4-treated cells formed irregularly shaped elongated structures with high numbers of protrusions (Figure 2D). In addition, BMP4 inhibited the proliferation of the MCF-10A cells by $69 \%$ at day 11 as compared to the vehicle $(\mathrm{P}<0.005$, Figure $2 \mathrm{E})$. Analysis of the area covered by cells revealed a maximum reduction of $51 \%$ at day 7 after BMP4 treatment $(\mathrm{P}<0.05$, Figure $2 \mathrm{~F})$.

\section{BMP4 induces different phenotypes in breast cancer cells in 3D}

Next we examined the effects of BMP4 in 3D cultures of four breast cancer cell lines. The cell lines were chosen based on our previous data showing a prominent 

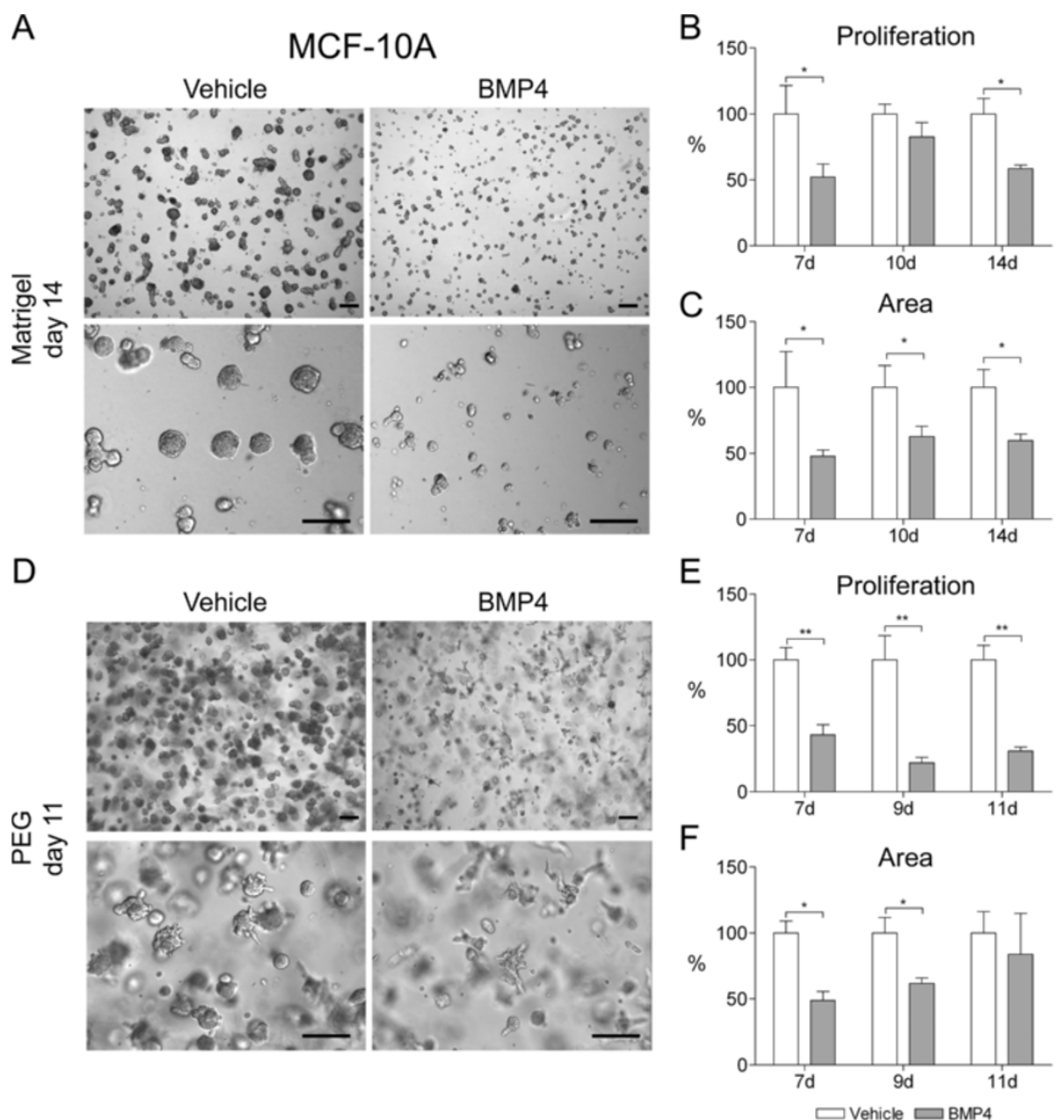

Figure 2 BMP4 inhibits MCF-10A cell growth in 3D cell culture. Cells were grown in Matrigel (A-C) or in PEG gel (D-F) supplemented with $100 \mathrm{ng} / \mathrm{ml} \mathrm{BMP4}$ or vehicle. Images were captured with Olympus IX71 microscope and representative examples from day 14 (Matrigel, panel A) and day 11 (PEG gel, panel D) are shown. Scale bars $200 \mu \mathrm{m}$. (b, e) Cell proliferation was measured using the alamarBlue reagent at indicated time points and relative proliferation (mean + s.d.) compared to vehicle is presented. $(\mathbf{C}, \mathbf{F})$ The area covered by cell clusters was measured from images taken at indicated time points using ImageJ and the relative mean area and s.d. compared to vehicle is shown. ${ }^{*} \mathrm{P}<0.05$, ${ }^{* *} \mathrm{P}<0.01$.

phenotype upon BMP4 stimulation in 2D; either G1 cell cycle arrest and growth inhibition (T-47D, BT-474, MDAMB-361) and/or increased migration (MDA-MB-231, MDA-MB-361) [10, unpublished]. T-47D cells formed irregular raft-like structures in Matrigel (Figure 3A). BMP4 treatment did not induce any obvious changes in the morphology of the cell clusters but inhibited cell proliferation $(29 \%$ at day $7,41 \%$ at day 10 and $10 \%$ at day 14 as compared to vehicle, $\mathrm{P}<0.05$, Figure $3 \mathrm{~A}-\mathrm{B})$. The size of the area covered by cells was similarly reduced by $43 \%$ and $39 \%$ at days 7 and 10 , respectively $(\mathrm{P}<0.05$, Figure $3 \mathrm{C})$. At day 14 the difference was $28 \%$ but just failed to reach statistical significance (Figure 3C). In PEG gel, the T-47D cell structures were either round or polygonal in shape, in both BMP4- and vehicle-treated samples (Figure 3D). BMP4 induced a distinct decrease in cell proliferation at days 11 and 14 (30\% and 51\%, respectively, as compared to vehicle, $\mathrm{P}<0.01$, Figure $3 \mathrm{E}$ ). Consequently, there was a significant reduction in the size of the cell area, ranging from $64 \%$ at day 7 to $79 \%$ at day $14(\mathrm{P}<0.05$, Figure $3 \mathrm{~F})$.

For BT-474 cells, the consequences of BMP4 treatment were first examined in 2D culture due to lack of previous information. A significant decrease in cell count was detected in BMP4-treated cells as compared to vehicle (30\% at day 3 and $70 \%$ at day $6, \mathrm{P}<0.01$, Additional file 2 : Figure S1). In Matrigel the cells formed dense, mostly round structures (Figure 4A). Proliferation was reduced by $26 \%$ already at day 7 and continued to decrease up to $36 \%$ at day 14 after BMP4-treatment $(\mathrm{P}<0.05$, Figure $4 \mathrm{~B})$. A concomitant reduction of $40 \%$ to $50 \%$ on average could be seen in the area measurements $(P<0.05$, Figure $4 \mathrm{C})$.

MDA-MB-361 cells grew very slowly in both $3 \mathrm{D}$ environments and therefore were allowed to grow up to 
A

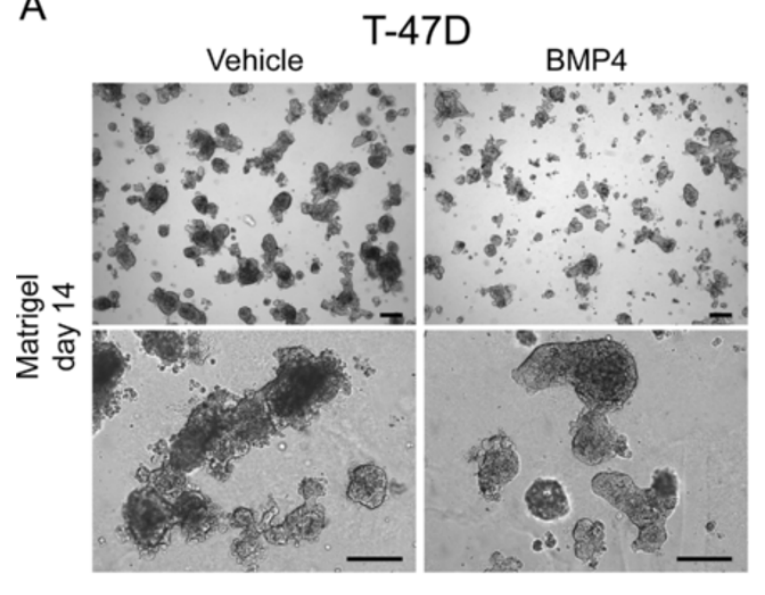

D

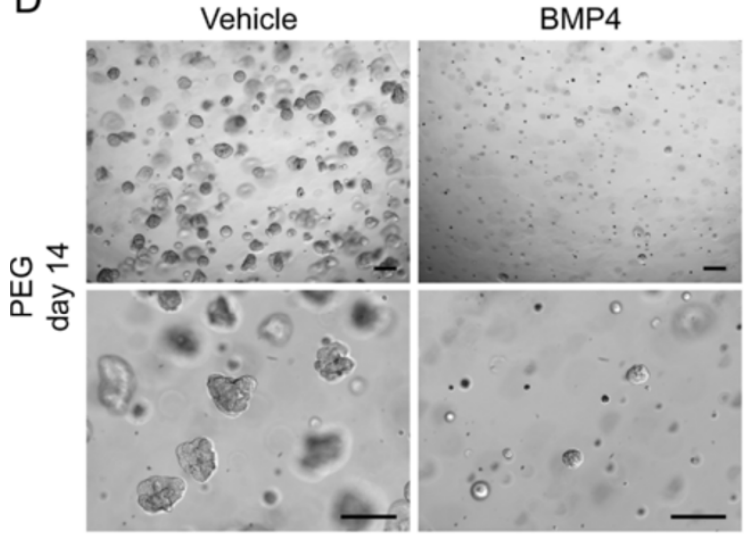

B

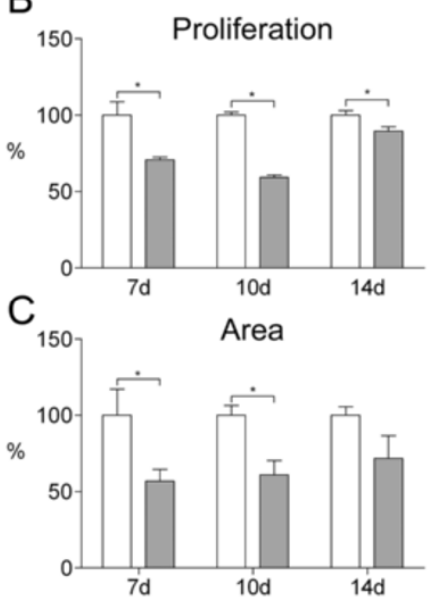

$\mathrm{E}$

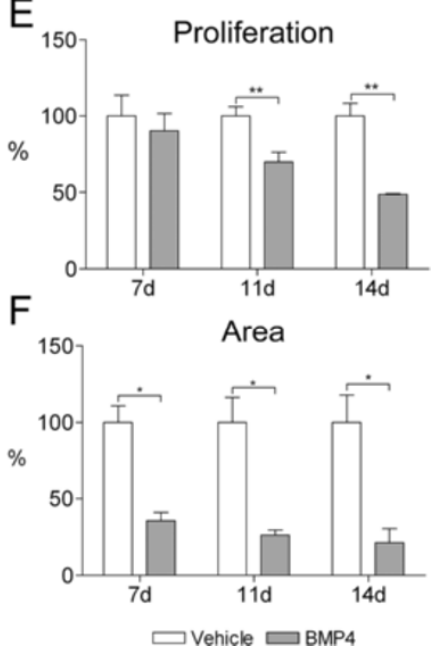

Figure 3 BMP4 inhibits T-47D cell growth in 3D cell culture. Cells were grown in Matrigel (A-C) or in PEG gel (D-F) and supplemented with $100 \mathrm{ng} / \mathrm{ml} \mathrm{BMP4}$ or vehicle. Images were taken as indicated in Figure 2 and representative examples from day 14 are shown. Scale bars $200 \mu$ m. (B, E) Cell proliferation and $(\mathbf{C}, \mathbf{F})$ area covered by cell clusters were measured and are presented as in Figure 2 , ${ }^{*} \mathrm{P}<0.05$, ${ }^{* *} \mathrm{P}<0.01$.

18 days (Additional file 3: Figure S2). In Matrigel, the cells formed small mostly round masses, and BMP4 treatment induced no consistent changes in proliferation, area or morphology of the cells (Additional file 3: Figure S2A-C). In contrast, in PEG gel BMP4 significantly decreased proliferation at day 11 through day 18 (15\% and $28 \%$, respectively, as compared to vehicle, $\mathrm{P}<0.01$, Additional file 3: Figure S2E). In addition, BMP4 decreased the size of the area covered by cells, with a maximum reduction of $48 \%$ at day 11 ( $\mathrm{P}<0.05$, Additional file 3: Figure S2F). However, no changes in the morphology of the cell structures were observed in PEG gel with both BMP4 and vehicle treatments resulting in round cell clusters.

MDA-MB-231 cells formed mostly dense and compact round or oval structures in Matrigel with occasional branches (Figure 5A). Interestingly, BMP4 had a major impact on the morphology of the cells. It induced the formation of large branching stellate structures, which extended over large areas of the gel (Figure 5A). The first evidence on this effect was seen already at day 7 , but it became prominent after 10 days in culture (Figure 5A). On the other hand, BMP4 did not have an effect on the proliferation of the MDA-MB-231 cells as measured by alamarBlue or the area covered by the cells (Figure $5 \mathrm{~B}$ and $5 \mathrm{C}$ ). It should be noted that the latter result is hindered by the difficulties in accurately measuring the area of the BMP4-induced stellate structures. In PEG gel, no branching was observed and the MDA-MB-231 cell masses were typically round or irregularly shaped in both BMP4- and vehicle-treated samples (Figure 5D). Interestingly, BMP4 significantly inhibited proliferation of the MDA-MB-231 cells in PEG gel, with a 36\% reduction by day $14(\mathrm{P}<0.01$, Figure $5 \mathrm{E})$. Similarly, the area covered by the cells was diminished by a maximum of $36 \%$ at day $11(\mathrm{P}<0.05$, Figure $5 \mathrm{~F})$. 

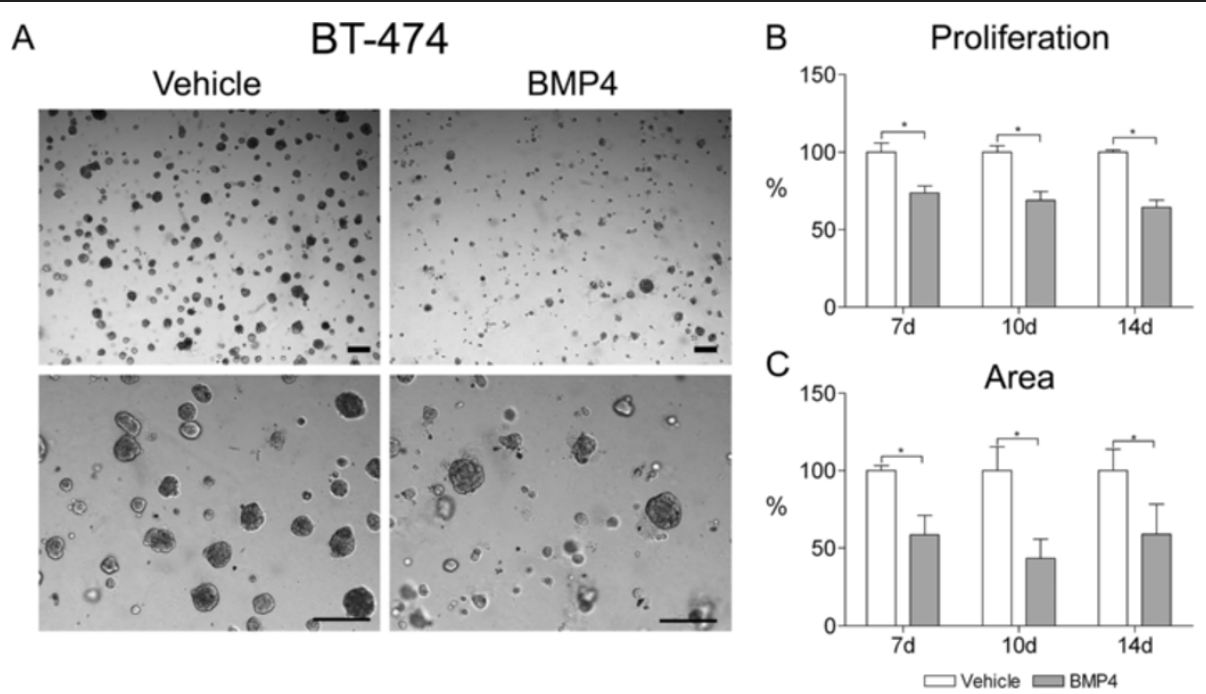

Figure 4 BMP4 inhibits BT-474 cell growth in 3D cell culture. (A) Cells were grown in Matrigel and supplemented with $100 \mathrm{ng} / \mathrm{ml}$ BMP4 or vehicle. Images were taken as indicated in Figure 2 and representative examples from day 14 are shown. Scale bars $200 \mu \mathrm{m}$. (B) Cell proliferation and $(\mathbf{C})$ area covered by cell clusters were measured and are presented as in Figure $2,{ }^{*} \mathrm{P}<0.05$.

\section{BMP4-induced growth arrest is partly explained by induction of p21 expression}

We have previously shown that the growth inhibition caused by BMP4 in breast cancer cell lines growing in monolayer culture is due to a G1 cell cycle arrest [10]. To investigate this further, the effect of BMP4 on the expression of 11 known cell cycle regulators was measured in T-47D and MDA-MB-361 cells grown for 24 hours in 2D. A change in the expression of the cell cycle inhibitor p21, phosphorylated CDC2 and Cyclins B1 and B2 was seen in both cell lines, with at least a 2 -fold difference in one of the cell lines (Additional file 4: Figure S3). Among these, induction of p21 was the most prominent (4.1-fold in MDA-MB-361 and 2.2-fold in T-47D) and was thus selected for further evaluation. We verified that $\mathrm{p} 21$ expression was also induced by BMP4 in 2D culture of MDA-MB-231 and BT-474 cells (Figure 6A). In MCF-10A cells, distinct p21 induction (1.8-fold) was evident only after a prolonged (5 days) BMP4 treatment (Figure 6A) and was accompanied by a G1 cell cycle arrest (G1 phase fraction $80 \%$ vs. $69 \%$ in BMP4- and vehicle-treated cells, respectively, $\mathrm{P}<0.05$, Figure 6B). In Matrigel, the p21 levels were determined at day 4 or 7 after BMP4 treatment. BMP4 had no effect on p21 expression in MCF-10A cells whereas it did induce p21 expression in T-47D, BT-474, MDA-MB-361 and MDA-MB-231 cells (Figure 6A).

\section{Induction of a stellate phenotype in MDA-MB-231 cells is MMP-dependent}

To confirm that the stellate phenotype induced in the MDA-MB-231 cells in Matrigel was indeed dependent on $\mathrm{BMP}$, the cells were treated with BMP4 together with a
BMP antagonist Gremlin, which inhibits the actions of BMP2, -4 and -7 [28]. Gremlin $(1 \mu \mathrm{g} / \mathrm{ml})$ alone had no effect on the morphology of the cells (Figure 7A). The cells treated with both Gremlin and BMP4 had similar morphology than vehicle-treated cells and thus Gremlin was able to reverse the stellate phenotype (Figure 7A).

We then speculated that the stellate phenotype may require the action of matrix metalloproteinases (MMPs). A broad-spectrum MMP inhibitor Batimastat was employed to test its potential in inhibiting the BMP4-induced phenotype. Batimastat $(10 \mu \mathrm{M})$ alone resulted in a moderate reduction of growth of the cells as compared to vehicle-treated cells (Figure 7B). However, Batimastat was able to inhibit the formation of BMP4-induced stellate structures and, somewhat surprisingly, the combination of Batimastat and BMP4 resulted in a pronounced reduction in the size of the cell structures (Figure $7 \mathrm{~B}$ ).

As the stellate phenotype was reversed by an MMP inhibitor, we next examined the contribution of individual MMPs to this phenotype. Using quantitative RT-PCR, the expression levels of seven $M M P$ s known to be targeted by Batimastat were measured in BMP4- and vehicle-treated MDA-MB-231 cells grown in Matrigel for 14 days. $M M P 2, M M P 7$ and $M M P 9$ were not expressed in the MDA-MB-231 cells at a sufficient level to allow accurate measurements and there was no difference in $A D A M 17$ expression between BMP4-and vehicle-treated cells (data not shown). In contrast, there was a dramatic 19-fold increase in $M M P 3$ expression $(\mathrm{P}<0.005)$ and a 3.7 -fold increase in $M M P 14$ expression $(\mathrm{P}<0.05)$ in $\mathrm{BMP} 4$-treated cells as compared to vehicle-treated cells. In addition, MMP1 expression was 4.3 times higher in BMP4-treated cells but the 

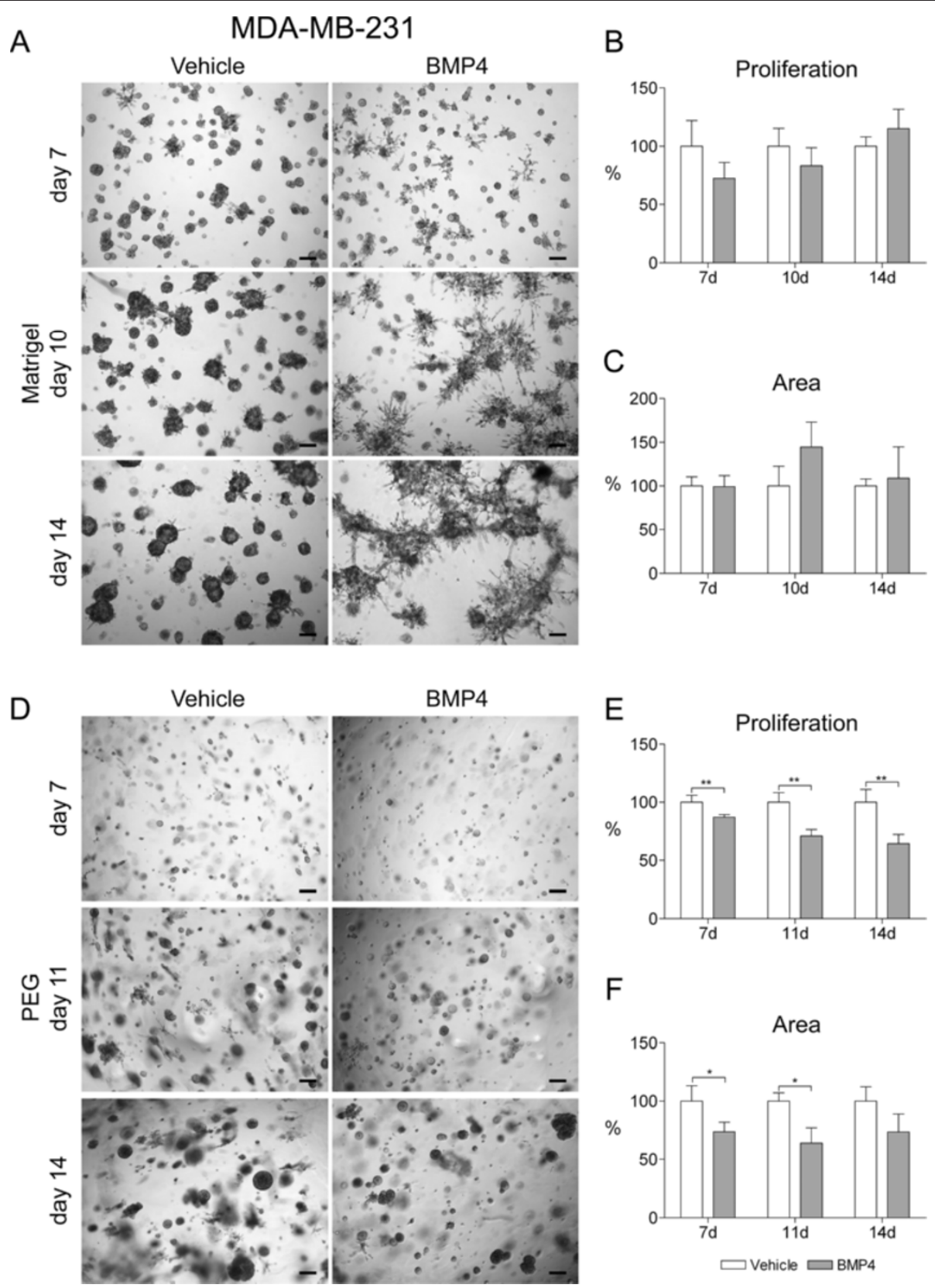

Figure 5 BMP4 induces a stellate phenotype and reduces the growth of the MDA-MB-231 cells in 3D cell culture. Cells were grown in Matrigel (A-C) or in PEG gel (D-F) supplemented with $100 \mathrm{ng} / \mathrm{ml} \mathrm{BMP4}$ or vehicle. Images were taken as indicated in Figure 2 and representative examples from days 7, 10 and 14 for Matrigel and days 7, 11 and 14 for PEG gel are shown. Scale bars $200 \mu \mathrm{m}$. (B, E) Cell proliferation and (C, F) area covered by cell clusters were measured and are presented as in Figure $2,{ }^{*} \mathrm{P}<0.05,{ }^{* * \mathrm{P}}<0.01$.

difference was not statistically significant. To further verify that the induction of $M M P 3$ and $M M P 14$ was exclusively related to the BMP4-induced stellate phenotype in MDA-MB-231 cells, we measured MMP3 and MMP14 mRNA levels in one of the non-stellate cell lines, BT-474, under similar conditions and found that in this case BMP4 did not induce the expression of these $M M P$ s (data not shown).

\section{Discussion}

We have previously shown that BMP4 reduces proliferation and increases migration of breast cancer cells in vitro [10]. As these results were derived from cells grown in 2D monolayer culture, we set out to analyze the effect of BMP4 in a more physiological setting by employing 3D culture systems. We approached this issue by using both a biological gel (Matrigel, the standard 3D 

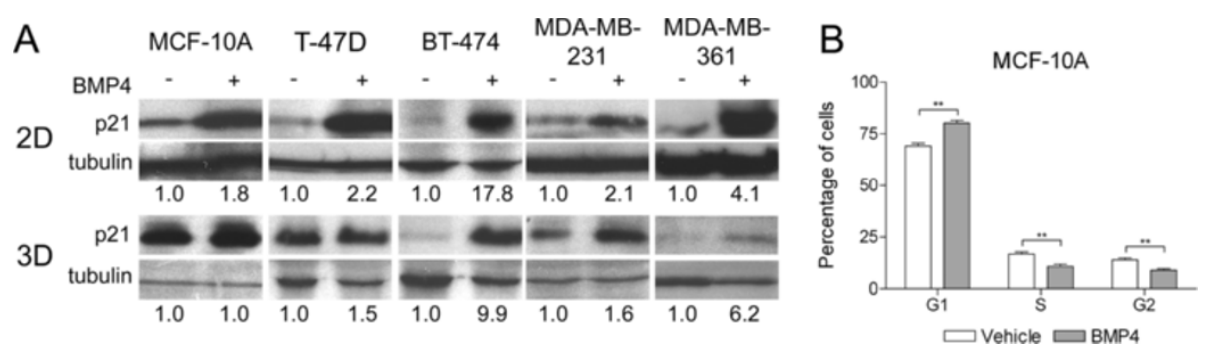

Figure 6 The expression of cell cycle inhibitor p21 is altered by BMP4. (A) MCF-10A cells were treated with $100 \mathrm{ng} / \mathrm{ml}$ BMP4 (+) or vehicle (-) for 5 days and the cancer cell lines for 24 hours when grown as monolayers (2D). In Matrigel (3D), the cells were grown and treated for 4 (MDA-MB-361) or 7 days. The expression of p21 was analyzed by western blot. Tubulin was used as a loading control and relative expression levels were calculated with ImageJ. (B) BMP4 treatment leads to G1 arrest of MCF-10A cells. The cell cycle was determined by flow cytometry at day 5 after the beginning of the treatments. The fraction (mean + s.d.) of cells in phases G1, S and G2 are shown. ${ }^{* *}$ $<0.01$.

culture environment) and a synthetic material with RGD peptides and MMP-degradable peptide links (PEG gel).

The two materials studied provided dissimilar 3D environments as first evidenced by differences in the morphology of the normal and cancer cell clusters. The MCF-10A

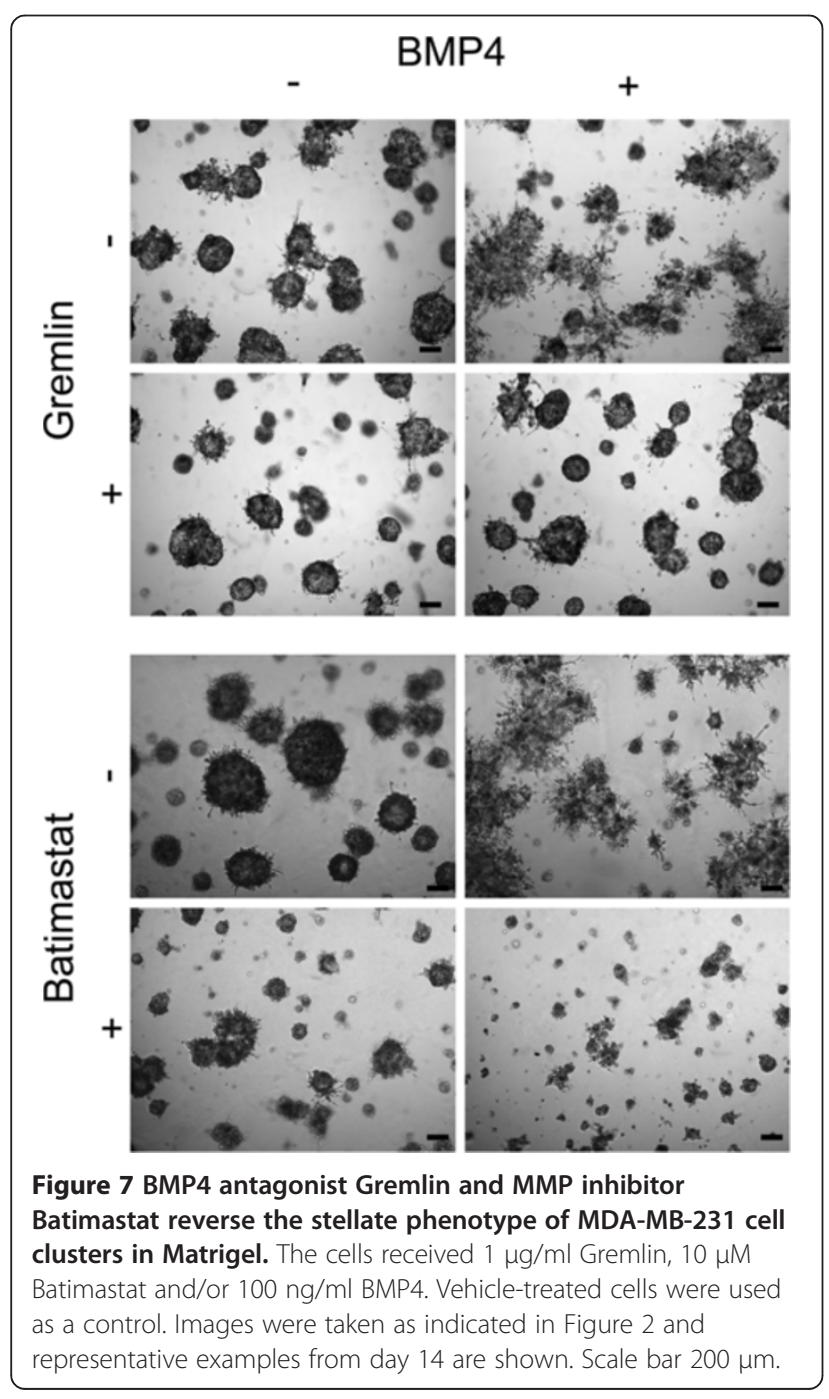

normal mammary epithelial cells had a polarized acini structure in Matrigel, as previously shown [17], while in PEG gel the cells formed irregular non-polarized structures. Similarly, the morphology of the different cancer cells varied between the two 3D models, with the structures formed in Matrigel again corresponding to those previously reported [18]. On a functional level, the growth response of cells to BMP4 treatment in PEG gel mirrored the $2 \mathrm{D}$ data, whereas in Matrigel more diverse effects were observed. These data could be explained by several factors. Matrigel contains multiple biologically active molecules, such as laminin, collagen IV and many growth factors [15], that are likely to impact the results obtained. Of these biologically active molecules, e.g. laminin-1 has been shown to be essential for correct polarization of primary luminal epithelial cells in collagen gels [29]. It has also been reported that $50 \mathrm{mM}$ RGD peptide is an optimal concentration for acinar growth of MCF-10A cells in polyethylene glycol tetravinyl sulfone (PEG-VS) gel [30]. A lower concentration of RGD $(50 \mu \mathrm{M})$ was present in the PEG gel used here, possibly explaining the lack of acinar formation. In addition, the stiffness and elasticity of the matrix is known to influence the cellular phenotype, including proliferation, differentiation and migration, in 3D environments [31-33]. To summarize, the differences in cell morphology and BMP4 response between the two materials tested demonstrate that the mere $3 \mathrm{D}$ architecture is not sufficient to mimic the biological effects of tissue environment. Based on the morphological characteristics, Matrigel seems to provide a more appropriate milieu for breast epithelial cells. While many synthetic 3D materials are entering the market, they should be used cautiously until their biological properties have been explored.

Previous data from us and others $[6,10]$ clearly demonstrate that BMP4 reduces the proliferation of breast cancer cells in 2D culture, and similar results have been reported in other tumor types [5,34-37]. Here we extend these findings and first show the same growth suppressive effect of BMP4 in MCF-10A normal immortalized breast epithelial 
cells both in 2D and 3D environment. The 3D data from the breast cancer cell lines were more diverse. In PEG gel, BMP4 administration led to reduced cell proliferation for all cell lines tested, whereas in Matrigel two out of four cell lines (MDA-MB-231 and MDA-MB-361) did not display growth inhibition upon BMP4 treatment. In the case of MDA-MB-361, the very slow growth rate of the cells in 3D may have contributed to these findings, although the difference between responses in PEG gel and Matrigel implies an actual effect triggered by the different environments. Furthermore, the growth suppressive action of BMP4 seen in MDA-MB-231 cells in 2D [10] disappeared in 3D Matrigel and was overcome by a migratory phenotype. The response of the cells to biological molecules is known to change drastically in 3D, for example, many anticancer drugs are less effective in 3D culture [38]. Our data now suggest that the ability of BMP4 to reduce cell growth in $3 \mathrm{D}$ strongly depends on the material used. Nevertheless, cell line specific differences also exist and further highlight the importance of testing the impact of biological factors, including BMP4, in a proper environment.

BMP4 has been reported to induce G1 cell cycle arrest in cancer cells [10,39-41]. We now show for the first time that the mechanism behind this cell cycle arrest in breast cancer cells is the increased expression of the cell cycle inhibitor p21. This result is in concordance with previous reports in 2D culture of various normal and neoplastic cells [41-45]. Additionally, BMP2 has been shown to induce p21 expression in breast cancer cells $[39,40,46]$. Interestingly, BMP4 induced p21 expression in MDA-MB-231 and MDA-MB-361 cells in 3D even in the absence of growth inhibition, suggesting that p21 alone is not sufficient to induce growth arrest in these cells in 3D. Furthermore in MCF-10A cells, p21 induction and G1 cell cycle arrest were not evident until day 5 in 2D culture, even though a significant growth reduction was seen already at day 3. Likewise, in MCF-10A 3D culture no p21 induction was observed even after 7 days of BMP4 treatment. Therefore it seems likely that other factors are involved in the BMP4-mediated growth regulation in MCF-10A cells. Examination of a panel of cell cycle regulators in T-47D and MDA-MB-361 cells in 2D showed that BMP4 influenced the expression of multiple cell cycle proteins, including $\mathrm{pCDC} 2$, Cyclin $\mathrm{B} 1$ and Cyclin B2. These or other cell cycle regulators could thus contribute to the observed growth inhibition in MCF-10A cells as well. Previous studies have reported dysregulation of several cell cycle associated proteins, including Cyclin $\mathrm{B} 1, \mathrm{CDC} 2, \mathrm{Rb}$, and E2F, after different stimuli in MCF-10A cells $[47,48]$, emphasizing the fact that multiple factors may be simultaneously involved. Further research is needed to identify the specific cell cycle regulators influenced by BMP4 treatment in MCF-10A cells.
In most cases, BMP4 had no effect on the morphology of the cells grown in 3D environment, with the exception of MDA-MB-231 cells and MCF-10A cells. In PEG gel, MCF-10A cells formed irregular structures with small protrusions, the number of which increased upon BMP4 stimulation, indicating increased migration and/or invasion. This is consistent with previous results showing BMP4-induced invasive properties in mouse mammary epithelial cells in collagen gels [49]. In Matrigel, MDAMB-231 cells formed stellate, branching structures in response to BMP4, which is in concert with previous observations of increased migration and invasion in 2D experiments $[6,10]$. Such structures were not observed in PEG gel, highlighting again the variation between the different 3D materials.

The MDA-MB-231 cells are known to be triple negative and represent the so-called basal subtype, whereas the remaining breast cancer cell lines used in this study are of luminal type [50]. We thus speculated whether the molecular subtype could explain the migratory response to BMP4 treatment seen only in MDA-MB-231 cells. To address this issue, we examined another triple negative basal breast cancer cell line, MDA-MB-436. However, the MDA-MB-436 cells were inherently migratory in Matrigel and BMP4 did not induce any additional effects (data not shown). Thus we conclude that the effects of BMP4 cannot be simply explained by the molecular subtype of the cell line. Neither could we link the BMP4-induced phenotypes to other known cell line characteristics, such as the histological type, mutational status, or tumorigenicity [18].

The BMP antagonist Gremlin was able to reverse the MDA-MB-231 stellate phenotype, demonstrating that the effect is truly due to the action of BMP4. Similarly, a broad spectrum MMP inhibitor Batimastat was able to inhibit the BMP4-induced branching of the MDA-MB-231 cells, indicating that the phenomenon required the action of matrix metalloproteinases (MMPs). Unexpectedly, Batimastat also reduced the growth of the cells, both with and without BMP4. MMPs have been shown to cleave intracellular or transmembrane proteins, thereby releasing factors that regulate cell proliferation, apoptosis, invasion and angiogenesis [51-54]. MMP9 has been particularly shown to possess growth-promoting effects [55,56]. Shon et al. [12] found BMP4 to suppress the activity of MMP9 in MDA-MB-231 cells, albeit in 2D culture, but in our 3D experiments the expression level of MMP9 was too low to allow accurate measurements and thus MMP9 is unlikely to explain the growth suppressive effects of Batimastat. Nevertheless, examination of the expression of $M M P_{\mathrm{s}}$ targeted by Batimastat revealed upregulation of MMP3 and MMP14 in BMP4-treated compared to vehicle-treated cells. Similar induction of $M M P 3$ or MMP14 expression was not seen in the non- 
migratory BT-474 cells, further suggesting a mechanistic link between these $M M P s$ and the stellate phenotype in MDA-MB-231 cells. A recent study also showed that BMP4 induces the expression of multiple MMPs, including $M M P 3$ and $M M P 14$, in mouse mammary fibroblasts and it also modestly induces the expression of $M M P 3$ in cancer associated human mammary fibroblasts and to a greater degree in normal human mammary fibroblasts [57]. In contrast, Otto et al. [58] found BMP4 to inhibit MMP3 mRNA and protein expression in C3H10T1/2 stem cells, and this inhibition was related to adipogenetic differentiation. These opposing results are likely to reflect cell-type and context-specific differences.

The exact mechanisms behind MMP3 and MMP14 induction upon BMP4 treatment in MDA-MB-231 cells remain to be revealed. $M M P 3$ has in its promoter a binding element for AP-1, which is in turn known to be regulated by BMP4 $[59,60]$, thereby representing a likely link between BMP4 and MMP3. However, previous data from other BMP/TGF- $\beta$ family members suggest that additional signaling pathways may also contribute to the MMP induction. In MDA-MB-435 melanoma cells, TGF$\beta$-induced upregulation of MMP14 has been shown to be dependent on the ERK1/2, PI3K, and JNK pathways [61] and in MDA-MB-231 cells TGF- $\beta$ induced the expression of many MMPs, including MMP14, through the p38 MAP kinase [62]. Similarly, BMP2 has been shown to increase the expression of $M M P 9$ in gastric cancer cells through AKT, ERK and NF- $\mathrm{B}$ signaling cascades [63]. Taken together, multiple signaling pathways may be involved in the BMP4-induced upregulation of MMP expression.

\section{Conclusions}

In conclusion, the data provided in this study demonstrate that Matrigel provides a more relevant environment to study the effects of biological factors on breast cancer cell behavior than the synthetic PEG gel. The responses of MDA-MB-231 and MDA-MB-361 cells to BMP4 were partly different in $2 \mathrm{D}$ than in $3 \mathrm{D}$ culture, thus strongly arguing for validation of 2D data in an appropriate 3D environment. Nevertheless, BMP4 retained its bifunctional role of reducing cell proliferation and inducing migration in $3 \mathrm{D}$, albeit not in the same cell line. Finally, this study also delivered further evidence on the molecular mechanisms behind the BMP4-induced phenotypes.

\section{Additional files}

Additional file 1: Table S1. Gene specific primers and probes. UPL (Universal Probe Library) probes were purchased from Roche.

Additional file 2: Figure S1. BMP4 treatment reduces BT-474 cell growth in 2D cell culture. Cells were grown in the presence of $100 \mathrm{ng} / \mathrm{ml}$ BMP4 or vehicle and proliferation was measured using the alamarBlue reagent and by counting the cells at indicated time points. Relative proliferation (mean + s.d.) compared to vehicle is shown. ${ }^{*} P<0.05$, **P $<0.01$.

Additional file 3: Figure S2. BMP4 does not influence MDA-MB-361 cells grown in Matrigel but decreases cell proliferation in PEG gels. Cells were grown in Matrigel $(a-c)$ or PEG gel $(d-f)$ supplemented with $100 \mathrm{ng} / \mathrm{ml} \mathrm{BMP4}$ or vehicle. Images were taken as indicated in Figure 2 and representative examples from day 14 are shown. Scale bars $200 \mu \mathrm{m}$. $(b, e)$ Cell proliferation and ( $c, f)$ area covered by cell clusters were measured and are presented as in Figure $2,{ }^{*} P<0.05$, ${ }^{*} P<0.01$.

Additional file 4: Figure S3. BMP4 influences the expression of cyclin B1, cyclin B2, pCDC2 and p21. The expression levels of a set of known cell cycle regulators were examined using western blotting. MDA-MB-361 and T-47D cells were grown as monolayers and harvested 24 hours after the treatment with $100 \mathrm{ng} / \mathrm{ml} \mathrm{BMP4}(+)$ or vehicle (-). Tubulin was used as a loading control and relative expression levels were calculated with ImageJ.

\section{Abbreviations}

2D: Two-dimensional; 3D: Three-dimensional; BMP4: Bone morphogenetic protein 4; MMP: Matrix metalloproteinase; PEG gel: Polyethyleneglycol gel; TGF- $\beta$ : Transforming growth factor $\beta$.

\section{Competing interests}

The authors declare that they have no competing interests.

\section{Authors' contributions}

MA and RJ conducted the experiments and wrote the manuscript. KJU consulted on the 3D culture experiments and participated in their design. ARM conducted initial experiments and helped in drafting the manuscript. EA and AK conceived of the study, participated in the design and helped to draft the manuscript. All authors approved the final version of the manuscript.

\section{Acknowledgements}

This study was supported by grants from the Finnish Cancer Organizations and the Competitive State Research Financing of the Expert Responsibility area of Tampere University Hospital (the unit of FimLab, grants 9 N021 and 9P003). We are grateful to Kati Rouhento for her skilful technical assistance and to Anni Järvinen and Anniina Brofeldt for their contribution in the experiments.

Received: 19 June 2013 Accepted: 17 September 2013

Published: 22 September 2013

\section{References}

1. Bragdon B, Moseychuk O, Saldanha S, King D, Julian J, Nohe A: Bone morphogenetic proteins: a critical review. Cell Signal 2011, 23:609-620.

2. Winnier G, Blessing M, Labosky PA, Hogan BL: Bone morphogenetic protein- 4 is required for mesoderm formation and patterning in the mouse. Genes Dev 1995, 9:2105-2116.

3. Sadlon TJ, Lewis ID, D'Andrea RJ: BMP4: its role in development of the hematopoietic system and potential as a hematopoietic growth factor. Stem Cells 2004, 22:457-474.

4. Cho KW, Kim JY, Song SJ, Farrell E, Eblaghie MC, Kim HJ, Tickle C, Jung HS: Molecular interactions between Tbx3 and Bmp4 and a model for dorsoventral positioning of mammary gland development. Proc Natl Acad Sci U S A 2006, 103:16788-16793.

5. Kallioniemi A: Bone morphogenetic protein 4-a fascinating regulator of cancer cell behavior. Cancer Genet 2012, 205:267-277.

6. Guo D, Huang J, Gong J: Bone morphogenetic protein 4 (BMP4) is required for migration and invasion of breast cancer. Mol Cell Biochem 2012, 363:179-190.

7. Alarmo EL, Kuukasjarvi T, Karhu R, Kallioniemi A: A comprehensive expression survey of bone morphogenetic proteins in breast cancer highlights the importance of BMP4 and BMP7. Breast Cancer Res Treat 2007, 103:239-246.

8. Davies SR, Watkins G, Douglas-Jones A, Mansel RE, Jiang WG: Bone morphogenetic proteins 1 to 7 in human breast cancer, expression pattern and clinical/prognostic relevance. J Exp Ther Oncol 2008, 7:327-338. 
9. Alarmo EL, Huhtala H, Korhonen T, Pylkkanen L, Holli K, Kuukasjarvi T, Parkkila S, Kallioniemi A: Bone morphogenetic protein 4 expression in multiple normal and tumor tissues reveals its importance beyond development. Mod Pathol 2013, 26:10-21.

10. Ketolainen JM, Alarmo EL, Tuominen VJ, Kallioniemi A: Parallel inhibition of cell growth and induction of cell migration and invasion in breast cancer cells by bone morphogenetic protein 4. Breast Cancer Res Treat 2010, 124:377-386.

11. Pal A, Huang W, Li X, Toy KA, Nikolovska-Coleska Z, Kleer CG: CCN6 Modulates BMP signaling via the smad-independent TAK1/p38 pathway, acting to suppress metastasis of breast cancer. Cancer Res 2012, 72(18):4818-4828.

12. Shon SK, Kim A, Kim JY, Kim Kl, Yang Y, Lim JS: Bone morphogenetic protein-4 induced by NDRG2 expression inhibits MMP-9 activity in breast cancer cells. Biochem Biophys Res Commun 2009, 385:198-203.

13. Pampaloni F, Reynaud EG, Stelzer EH: The third dimension bridges the gap between cell culture and live tissue. Nat Rev Mol Cell Biol 2007, 8:839-845.

14. Tibbitt MW, Anseth KS: Hydrogels as extracellular matrix mimics for $3 \mathrm{D}$ cell culture. Biotechnol Bioeng 2009, 103:655-663.

15. Kleinman HK, Martin GR: Matrigel: basement membrane matrix with biological activity. Semin Cancer Biol 2005, 15:378-386

16. Cushing MC, Anseth KS: Materials science, Hydrogel cell cultures. Science 2007, 316:1133-1134.

17. Debnath J, Muthuswamy SK, Brugge JS: Morphogenesis and oncogenesis of MCF-10A mammary epithelial acini grown in three-dimensional basement membrane cultures. Methods 2003, 30:256-268.

18. Kenny PA, Lee GY, Myers CA, Neve RM, Semeiks JR, Spellman PT, Lorenz K, Lee EH, Barcellos-Hoff MH, Petersen OW, Gray JW, Bissell MJ: The morphologies of breast cancer cell lines in three-dimensional assays correlate with their profiles of gene expression. Mol Oncol 2007, 1:84-96.

19. Schindler M, Ahmed I, Kamal J, Nur-E-Kamal A, Grafe TH, Young Chung H, Meiners S: A synthetic nanofibrillar matrix promotes in vivo-like organization and morphogenesis for cells in culture. Biomaterials 2005 26:5624-5631

20. Mahoney MJ, Anseth KS: Three-dimensional growth and function of neural tissue in degradable polyethylene glycol hydrogels. Biomaterials 2006, 27:2265-2274.

21. Salinas CN, Anseth KS: The enhancement of chondrogenic differentiation of human mesenchymal stem cells by enzymatically regulated RGD functionalities. Biomaterials 2008, 29:2370-2377.

22. Ridky TW, Chow JM, Wong DJ, Khavari PA: Invasive three-dimensional organotypic neoplasia from multiple normal human epithelia. Nat Med 2010, 16:1450-1455.

23. Ghosh S, Spagnoli GC, Martin I, Ploegert S, Demougin P, Heberer M, Reschner A: Three-dimensional culture of melanoma cells profoundly affects gene expression profile: a high density oligonucleotide array study. J Cell Physiol 2005, 204:522-531.

24. Le Beyec J, Xu R, Lee SY, Nelson CM, Rizki A, Alcaraz J, Bissell MJ: Cell shape regulates global histone acetylation in human mammary epithelial cells. Exp Cell Res 2007, 313:3066-3075.

25. Blum JL, Zeigler ME, Wicha MS: Regulation of rat mammary gene expression by extracellular matrix components. Exp Cell Res 1987, 173:322-340.

26. Parssinen J, Alarmo EL, Karhu R, Kallioniemi A: PPM1D silencing by RNA interference inhibits proliferation and induces apoptosis in breast cancer cell lines with wild-type p53. Cancer Genet Cytogenet 2008, 182:33-39.

27. Parssinen J, Kuukasjarvi T, Karhu R, Kallioniemi A: High-level amplification at 17q23 leads to coordinated overexpression of multiple adjacent genes in breast cancer. Br J Cancer 2007, 96:1258-1264.

28. Gazzerro E, Canalis E: Bone morphogenetic proteins and their antagonists. Rev Endocr Metab Disord 2006, 7:51-65.

29. Gudjonsson T, Ronnov-Jessen L, Villadsen R, Rank F, Bissell MJ, Petersen OW: Normal and tumor-derived myoepithelial cells differ in their ability to interact with luminal breast epithelial cells for polarity and basement membrane deposition. J Cell Sci 2002, 115:39-50.

30. Weiss MS, Bernabe BP, Shikanov A, Bluver DA, Mui MD, Shin S, Broadbelt L, Shea LD: The impact of adhesion peptides within hydrogels on the phenotype and signaling of normal and cancerous mammary epithelial cells. Biomaterials 2012, 33:3548-3559.

31. Huang G, Wang L, Wang S, Han Y, Wu J, Zhang Q, Xu F, Lu TJ: Engineering three-dimensional cell mechanical microenvironment with hydrogels. Biofabrication 2012, 4:042001.
32. Lance A, Yang CC, Swamydas M, Dean D, Deitch S, Burg KJ, Dreau D: Increased extracellular matrix density decreases MCF10A breast cell acinus formation in 3D culture conditions. J Tissue Eng Regen Med 2013. e-pub ahead of print 12 February 2013.

33. Storm C, Pastore JJ, MacKintosh FC, Lubensky TC, Janmey PA: Nonlinear elasticity in biological gels. Nature 2005, 435:191-194.

34. Shirai YT, Ehata S, Yashiro M, Yanagihara K, Hirakawa K, Miyazono K: Bone morphogenetic protein-2 and -4 play tumor suppressive roles in human diffuse-type gastric carcinoma. Am J Pathol 2011, 179:2920-2930.

35. Virtanen S, Alarmo EL, Sandstrom S, Ampuja M, Kallioniemi A: Bone morphogenetic protein -4 and -5 in pancreatic cancer-novel bidirectional players. Exp Cell Res 2011, 317:2136-2146

36. Zhou Z, Sun L, Wang Y, Wu Z, Geng J, Miu W, Pu Y, You Y, Yang Z, Liu N: Bone morphogenetic protein 4 inhibits cell proliferation and induces apoptosis in glioma stem cells. Cancer Biother Radiopharm 2011, 26:77-83.

37. Hjertner $\mathrm{O}$, Hjorth-Hansen H, Borset M, Seidel C, Waage A, Sundan A: Bone morphogenetic protein-4 inhibits proliferation and induces apoptosis of multiple myeloma cells. Blood 2001, 97:516-522

38. Smalley KS, Lioni M, Herlyn M: Life isn't flat: taking cancer biology to the next dimension. In Vitro Cell Dev Biol Anim 2006, 42:242-247.

39. Ghosh-Choudhury N, Ghosh-Choudhury G, Celeste A, Ghosh PM, Moyer M, Abboud SL, Kreisberg J: Bone morphogenetic protein-2 induces cyclin kinase inhibitor p21 and hypophosphorylation of retinoblastoma protein in Estradiol-treated MCF-7 human breast cancer cells. Biochim Biophys Acta 2000, 1497:186-196.

40. Ghosh-Choudhury N, Woodruff K, Qi W, Celeste A, Abboud SL, Ghosh Choudhury G: Bone morphogenetic protein-2 blocks MDA MB 231 human breast cancer cell proliferation by inhibiting cyclin-dependent kinase-mediated retinoblastoma protein phosphorylation. Biochem Biophys Res Commun 2000, 272:705-711.

41. Brubaker KD, Corey E, Brown LG, Vessella RL: Bone morphogenetic protein signaling in prostate cancer cell lines. J Cell Biochem 2004, 91:151-160.

42. Chang SF, Chang TK, Peng HH, Yeh YT, Lee DY, Yeh CR, Zhou J, Cheng CK, Chang CA, Chiu JJ: BMP-4 induction of arrest and differentiation of osteoblast-like cells via p21 CIP1 and p27 KIP1 regulation. Mol Endocrinol 2009, 23:1827-1838.

43. Jeffery TK, Upton PD, Trembath RC, Morrell NW: BMP4 inhibits proliferation and promotes myocyte differentiation of lung fibroblasts via Smad1 and JNK pathways. Am J Physiol Lung Cell Mol Physiol 2005, 288:L370-8.

44. Su D, Zhu S, Han X, Feng Y, Huang H, Ren G, Pan L, Zhang Y, Lu J, Huang B: BMP4-smad signaling pathway mediates adriamycin-induced premature senescence in lung cancer cells. J Biol Chem 2009, 284:12153-12164.

45. Zhu D, Wu J, Spee C, Ryan SJ, Hinton DR: BMP4 mediates oxidative stressinduced retinal pigment epithelial cell senescence and is overexpressed in age-related macular degeneration. J Biol Chem 2009, 284:9529-9539.

46. Pouliot F, Labrie C: Role of Smad1 and Smad4 proteins in the induction of p21WAF1, Cip1 during bone morphogenetic protein-induced growth arrest in human breast cancer cells. J Endocrinol 2002, 172:187-198.

47. Hawkes WC, Wang TT, Alkan Z, Richter BD, Dawson K: Selenoprotein W modulates control of cell cycle entry. Biol Trace Elem Res 2009, 131:229-244.

48. Hsieh TC, Wijeratne EK, Liang JY, Gunatilaka AL, Wu JM: Differential control of growth, cell cycle progression, and expression of NF-kappaB in human breast cancer cells MCF-7, MCF-10A, and MDA-MB-231 by ponicidin and oridonin, diterpenoids from the Chinese herb rabdosia rubescens. Biochem Biophys Res Commun 2005, 337:224-231.

49. Montesano R: Bone morphogenetic protein-4 abrogates lumen formation by mammary epithelial cells and promotes invasive growth. Biochem Biophys Res Commun 2007, 353:817-822.

50. Kao J, Salari K, Bocanegra M, Choi YL, Girard L, Gandhi J, Kwei KA, Hernandez-Boussard T, Wang P, Gazdar AF, Minna JD, Pollack JR: Molecular profiling of breast cancer cell lines defines relevant tumor models and provides a resource for cancer gene discovery. PLoS One 2009, 4:e6146.

51. Patel TR, Butler G, McFarlane A, Xie I, Overall CM, Stetefeld J: Site specific cleavage mediated by MMPs regulates function of agrin. PLoS One 2012 7:e43669.

52. Meighan PC, Meighan SE, Rich ED, Brown RL, Varnum MD: Matrix metalloproteinase- 9 and -2 enhance the ligand sensitivity of photoreceptor cyclic nucleotide-gated channels. Channels (Austin) 2012, 6:181-196

53. Egeblad M, Werb Z: New functions for the matrix metalloproteinases in cancer progression. Nat Rev Cancer 2002, 2:161-174. 
54. Hua $H$, Li M, Luo T, Yin Y, Jiang Y: Matrix metalloproteinases in tumorigenesis: an evolving paradigm. Cell Mol Life Sci 2011, 68:3853-3868.

55. Coussens LM, Tinkle CL, Hanahan D, Werb Z: MMP-9 supplied by bone marrow-derived cells contributes to skin carcinogenesis. Cell 2000, 103:481-490.

56. Dufour A, Sampson NS, Li J, Kuscu C, Rizzo RC, Deleon JL, Zhi J, Jaber N, Liu E, Zucker S, Cao J: Small-molecule anticancer compounds selectively target the hemopexin domain of matrix metalloproteinase-9. Cancer Res 2011, 71:4977-4988

57. Owens P, Polikowsky H, Pickup MW, Gorska AE, Jovanovic B, Shaw AK, Novitskiy SV, Hong CC, Moses HL: Bone morphogenetic proteins stimulate mammary fibroblasts to promote mammary carcinoma cell invasion. PLoS One 2013, 8:e67533.

58. Otto TC, Bowers RR, Lane MD: BMP-4 treatment of $\mathrm{C} 3 \mathrm{H} 10 \mathrm{~T} 1 / 2$ stem cells blocks expression of MMP-3 and MMP-13. Biochem Biophys Res Commun 2007, 353:1097-1104.

59. Piperi C, Papavassiliou AG: Molecular mechanisms regulating matrix metalloproteinases. Curr Top Med Chem 2012, 12:1095-1112.

60. Lee SY, Yoon J, Lee MH, Jung SK, Kim DJ, Bode AM, Kim J, Dong Z: The role of heterodimeric AP-1 protein comprised of JunD and c-Fos proteins in hematopoiesis. J Biol Chem 2012, 287:31342-31348.

61. Kuo YC, Su CH, Liu CY, Chen TH, Chen CP, Wang HS: Transforming growth factor-beta induces CD44 cleavage that promotes migration of MDA-MB $-435 \mathrm{~s}$ cells through the up-regulation of membrane type 1-matrix metalloproteinase. Int J Cancer 2009, 124:2568-2576.

62. Gomes LR, Terra LF, Wailemann RA, Labriola L, Sogayar MC: TGF-beta1 modulates the homeostasis between MMPs and MMP inhibitors through p38 MAPK and ERK1/2 in highly invasive breast cancer cells. BMC Cancer 2012, 12:26-2407. 12-26.

63. Kang MH, Oh SC, Lee HJ, Kang HN, Kim JL, Kim JS, Yoo YA: Metastatic function of BMP-2 in gastric cancer cells: the role of PI3K/AKT, MAPK, the NF-kappaB pathway, and MMP-9 expression. Exp Cell Res 2011, 317:1746-1762.

\section{doi:10.1186/1471-2407-13-429}

Cite this article as: Ampuja et al: BMP4 inhibits the proliferation of breast cancer cells and induces an MMP-dependent migratory phenotype in MDA-MB-231 cells in 3D environment. BMC Cancer 2013 13:429.

\section{Submit your next manuscript to BioMed Central and take full advantage of:}

- Convenient online submission

- Thorough peer review

- No space constraints or color figure charges

- Immediate publication on acceptance

- Inclusion in PubMed, CAS, Scopus and Google Scholar

- Research which is freely available for redistribution 